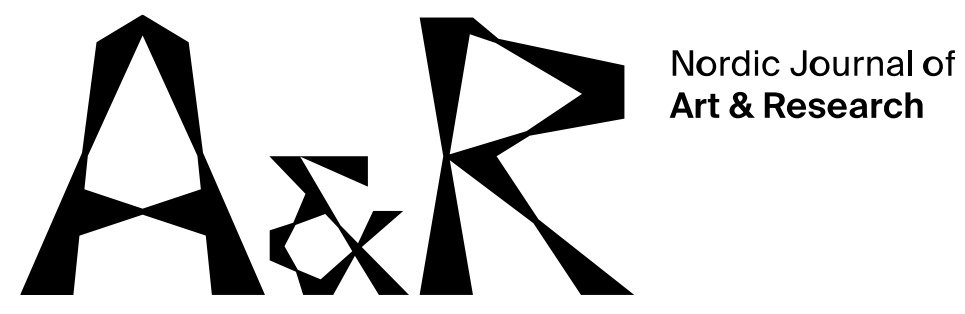

\title{
In the Footsteps of an Observer - Looking at Edvard Munch in Åsgårdstrand
}

\author{
IImi Gutzeit Mathiesen ${ }^{1}$ \\ Oslo Metropolitan University
}

\begin{abstract}
This article presents an arts based approach to some of the motifs that Edvard Munch painted during his many stays in the Norwegian town of Åsgårdstrand. The author examines the relationship between Munch's and her own observations made from the very same vantage points in the landscapes. The theoretical thrust of the article is informed by arts based research as promoted by art education theorists Barone and Eisner (2012) and art therapy researcher McNiff (2013). It is also inspired by Pink's text "Doing sensory ethnography" (2009), which highlights the multisensory experience and recognises the significance of the researcher's own presence in the data collection process.
\end{abstract}

A key tool in the research project was a tablet device (iPad), used both as a camera in the field and as a tool for creative artistic exploration in practice. The method involved digitally painting Munch's figures onto photos taken from the same places as the artist must have stood when inspired to paint his famous pictures. The author argues that a tablet with artistic software applications can serve as a versatile and handy "portable studio", facilitating immediate first-hand experience and understanding. The concluding discussion focuses on how this practical arts based approach to the work of a famous artist can be implemented in an art education setting. 
IImi Gutzeit Mathiesen.

In the Footsteps of an Observer - Looking at Edvard Munch in Åsgårdstrand

Keywords: artistic research, arts-based research, sensory ethnography, Edvard Munch, drawing, tablet device, iPad

\section{Introduction}

It is early April, and I am participating in a guided tour of Munch's old studio in Åsgårdstrand. Through a balcony facing the garden, we enter a living room equipped with furniture from Munch's time. Placed in the middle - dominating the room - is a bed with a beautifully embroidered bedspread that shines yellow in the light from the windows. The spring light flows in through two windows with tiny windowpanes. The corner cabinet contains painting equipment: a palette, half-empty paint tubes, paintbrushes, bottles with turpentine and glazes. The paint tubes look like the tubes in my own studio. It seems as though Munch was just here, or that he will return at any moment. A mirror adorns the wall, along with Munch's suit and hat. I can see my own face in Munch's mirror. I pick up my tablet device and take a few selfies. I am caught by the time-worn mirror, wondering if this very same mirror also captured Munch's face and features. I remember that Munch observed himself all his life, just as he so cleverly observed others. He was a master observer - and a master at reproducing what he saw in the form of paintings that have proven to be timeless. (Author's log, April, 2018)

This article presents an experience-based research approach to the works of a famous artist. The point of departure is Edvard Munch's gaze - and my own gaze as an artist and researcher when given the opportunity to "walk in Munch's footsteps" in Åsgårdstrand, the town where he created many of his most famous paintings, including "Melancholy"(1892), "The Voice" (1896) and "The Girls on the Pier"(1901). The essence of the article centres around my research project involving the use of a tablet device (iPad) as both a camera in the field and a tool for artistic exploration in practice. Using this tool, I examine the relationship between Munch's observations and my own observations made from the very same vantage points in the Åsgårdstrand landscape. My personal experience of this artistic practice, and my following reflections on the process, are key aspects of the article that structure my arguments. Towards the end of the article, I discuss how this method, as well as my general research approach, can be of relevance to art in educational settings and serve to inspire other artists and art students.

I am fully aware that I am not the first artist to be inspired by Munch. In 2015, Bjarne Melgaard raised controversy in the Norwegian art world with his radical Munch-based artworks in the noteworthy exhibition Melgaard + Munch at the Munch museum. In Melgaard's expressive brushwork, one can find clear traces of Munch's late painting style and spontaneous line drawing. Against the backdrop of their own times, both Munch and Melgaard deal with fundamental themes confronted by the human being 
IImi Gutzeit Mathiesen.

In the Footsteps of an Observer - Looking at Edvard Munch in Åsgårdstrand

in modern society: sexuality, gender, death, loneliness and alienation (Munchmuseet, 2015). As part of the celebration of the $150^{\text {th }}$ anniversary of Munch's birth, Marina Abramovic created her own version of "The Scream" (1893) in Ekeberg Sculpture Park, at the exact same spot where Munch was inspired to paint his famous work. The result was three interactive works of art; sculpture, performance and video works (Ekebergparken, 2013). While I have been inspired by these artworks and the discourse they have been surrounded by, the aim of my own approach has not primarily been to create art, but to engage with arts based research as a pathway to understanding processes of observation and interpretation.

The theoretical thrust of this article is informed in particular by arts based research, and theories promoted by art education theorists Tom Barone and Elliot Eisner (2012), art therapy researcher Shaun McNiff (2013) and choreographer and art education professor Tone Pernille Østern (2017). These approaches involve integrating artistic activities into the research process itself (Eisner, 1998, p. 21). Accordingly, I have used my own artistic expressions as a means of enquiry to obtain a sense of "artistic knowing" (McNiff, 2011, p. 38). My approach is also informed by sensory ethnography, which involves a way of thinking that highlights the multisensoriality of experience, perception, knowing and practice, while also recognising the influence of the researcher's own presence in data collection (Pink, 2009). In line with this thinking, my approach to Munch is based on my own experience and does not claim to produce an objective or truthful account of reality. My aim is to offer a version of my experiences that is as loyal as possible to the context, my own bodily presence and the actions through which knowledge was produced (Pink, 2009).

\section{Arts based research}

The idea of arts based research can be attributed to Elliot W. Eisner. Originally a painter, he emphasises how his own artistic experience has contributed to shaping his ideas about seeing and solving problems as a researcher in the academic field (Eisner, 1998, p. 11). Eisner relates the act of drawing to the artistic gaze - to what we are trained to see. Consequently, he does not consider the artistic researcher to be an objective viewer: "What we see is frequently influenced by what we know. This influence is graphically illustrated in learning to draw" (Eisner, 1998, p. 67). Besides this focus on the trained eye, arts based research also places an emphasis on "connoisseurship", or the researcher's understanding and empathic involvement (Barone \& Eisner, 2012, p. xii). With reference to Susanne Langer (1957), Barone and Eisner assert that "arts based research is a process that uses the expressive qualities of form to convey meaning" (Barone \& Eisner, 2012, p. 9). 
IImi Gutzeit Mathiesen.

In the Footsteps of an Observer - Looking at Edvard Munch in Åsgårdstrand

Shaun McNiff echoes Barone and Eisner's description by describing art-based research (sic) as a systematic use of the artistic process, the unique feature being the production of art by the researcher (McNiff, 2008, p. 29; 2013, p. 55). Based on research in applied arts and art therapy, McNiff argues that making art should be regarded as a primary mode of enquiry with its own set of research methodologies, rather than borrowing research approaches from other disciplines in order to study artistic processes.

Various other directions and concepts have emerged since Eisner introduced the term "arts based research" at Stanford University in 1993. Examples are: artistic research, practice-led research, art as research, A/R/Tography and performative research (Almqvist \& Vist, 2019, p. 44; Østern, 2017, p. 99). I have mainly chosen Barone and Eisner's approach and terminology since their point of departure is firmly planted in the empathic experience of the artist, which resonates strongly with my own work as an artist and a researcher in this project. In my understanding, it is important to underline that arts based research is not only "a literal description of a state of affairs; it is an evocative and emotionally drenched expression that makes it possible to know how others feel" (Barone \& Eisner, 2012, p. 9). Additionally, with reference to the work of Tone Pernille Østern, I see my approach as "researching with the arts" - as an opportunity to use my own artistic gaze, skills and experience to investigate Munch's motifs (Østern, 2017, p. 8). I not only reflect, but also reproduce and elaborate on Munch's motifs by repainting his characters onto my own photographs taken in his Åsgårdstrand neighbourhood. In this way, I use my artistic knowledge and agency to explore my connections to Munch's artwork and search for alternative approaches to his paintings.

\section{A personal approach}

My approach to investigating Munch's work is both professional and deeply personal. It is informed by my training as an artist as well as my experience and my own preconceptions - my ways of seeing art are influenced by my "connoisseurship" (Eisner, 1998). Eisner reminds us that the term connoisseurship derivers from the Latin cognoscere, meaning "to know": "In the visual arts, to know depends upon the ability to see, not merely look" (p. 6). He uses the wine connoisseur as an example to point out how connoisseurship is useful when trying to differentiate among the qualities we attend to (p. 63). My own ways of seeing - my gaze - is not that of the wine connoisseur, but that of a practicing artist who has produced images in the field of visual arts for many years. I started my career with several years of training, the first two years at a vocational school of fine arts. As students, we worked with basic exercises such as observation studies of life models standing in a certain position for long periods of time. We also worked with observations and interpretations of still life: 
IImi Gutzeit Mathiesen.

In the Footsteps of an Observer - Looking at Edvard Munch in Åsgårdstrand

motifs with jars, vases and fruit. The observations taught me to see shades of colour, like the blue colours in a shadow that at first glance seemed only "black". We trained our gaze to see that the forehead of a human being could be almost olive green and that the colour of a leg may have a chilly crimson shade. We trained the eye, and the hand's ability to interpret what we had before us with increasingly confident lines.

Additionally, adopting an "artistic gaze" is concerned with more than just these rather technical aspects that are often seen as building blocks to becoming a professional artist. Our gaze is socially constructed, and what we see, how we see and how we understand what we see is always influenced by learnt assumptions concerning taste, beauty, truth, class and gender (Berger, 2008). Artistic training at an art academy is embedded in particular value systems that shape the teaching and the art students' gaze. In the academy context, the artistic gaze is largely taken for granted. For me, this training, together with my subsequent experiences with observing and producing art, has constructed my own personal gaze, as well as the unique connoisseurship I mobilised when engaging with Munch's art and historical environment.

My connoisseurship involves both my socially constructed ways of seeing and my reflections and readings of Munch's work. Generally speaking, I experience his use of colours, and the way in which he draws up his motifs, as "tight" and at the same time playful and easy. I notice a lot of dimensional space in his paintings and drawings, and many features that may seem unfinished. I would argue, however, that he has stopped just in time - where other artists might try to adjust and correct, going over details, decorating the surface, completing seemingly unfinished lines that the gaze of the observer is able to understand as connected. Looking at Munch's paintings, I am reminded of my own struggles to keep my artistic expression simple and direct - without overworking lines and colours. Details can complement a motif, but they can also "kill it".

\section{Åsgårdstrand}

The further discussion in this article is based on my experience of participating in a guided tour of Edvard Munch's home and studio in Åsgårdstrand where he lived and worked for long periods of his life. Of all the places Edvard Munch lived and worked as an artist, it is perhaps in Åsgårdstrand that he has left the most obvious traces. Here lies the only preserved home of Edvard Munch, where he lived most of the summers from 1889 to 1905 . The surrounding landscape is featured in many of the pictures he painted during this period. The property is today preserved as a museum.

On the way to the house, the museum guide pointed out some of the motifs that Munch painted: "The Girls on the Pier" "(1901) (Fig. 1) and "Melancholy" (1892) (Fig. 
IImi Gutzeit Mathiesen.

In the Footsteps of an Observer - Looking at Edvard Munch in Åsgårdstrand

5). My attention was drawn to a large rock looming in the background behind the man portrayed in "Melancholy". It was exciting for me to see the starting point of a motif I know so well - and my curiosity was roused. Did Munch really paint what he saw; the rocks as they really were and not just his idea of rocks? Did he actually portray the rocks? And the trees?

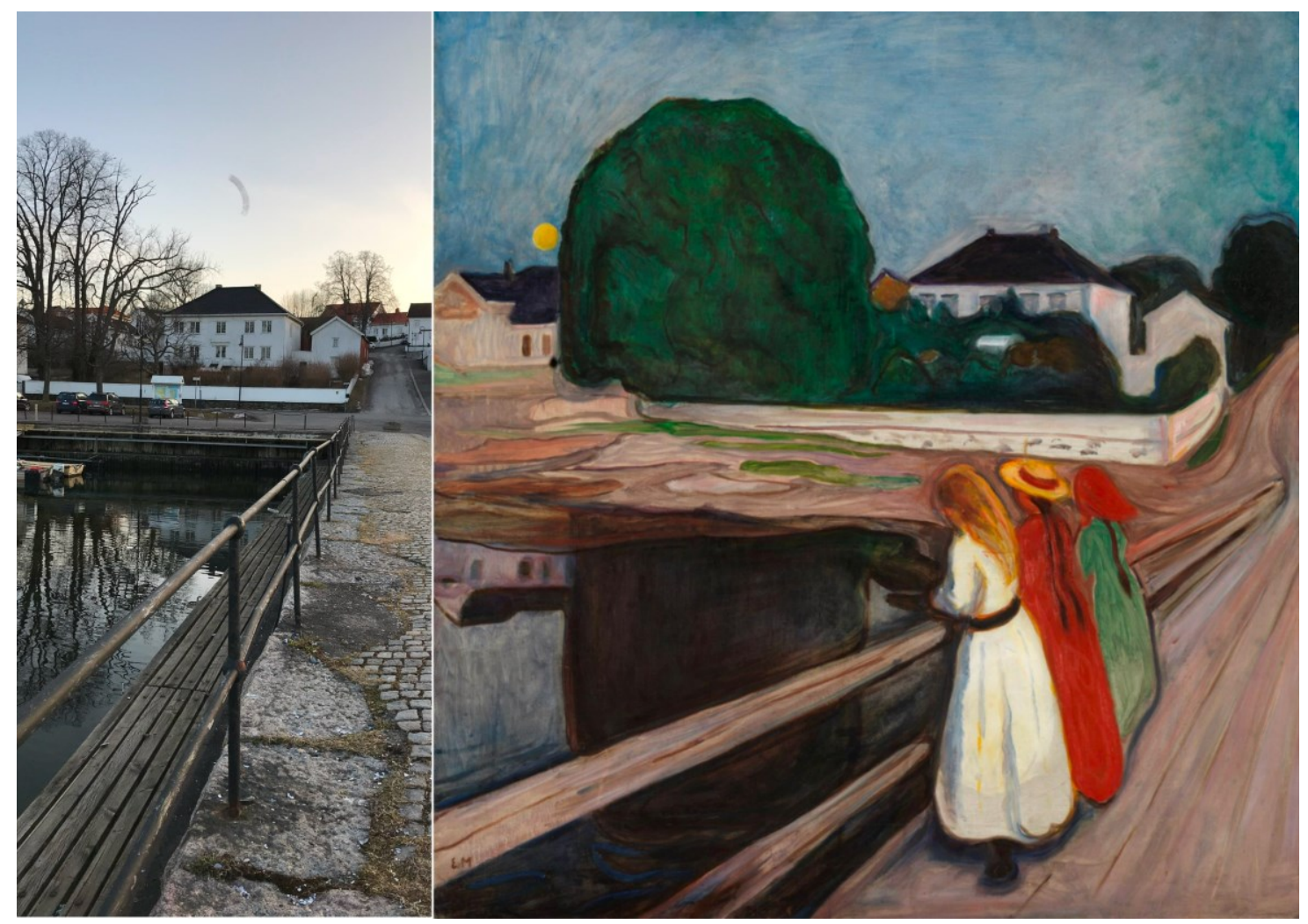

Figure 1. Left: Photo by the author, Åsgårdstrand, April 2018. Right: The girls on the pier", Edvard Munch,1901. Photo: Nasjonalmuseet/Børre Høstland (Free use. Creative Commons - CC-BY)

I was surprised to see how faithful Munch was towards what he observed in Åsgårdstrand. The size of the houses and the relationship between them, the location of the trees and the perspective. Munch himself has commented on his own artistic approach: "I don't paint what I see but what I saw" (Stang, 1977, p. 34). I had previously understood this well-known quote as meaning that he took great freedoms in his work, using his own memory to create a collage of what seemed most important. My observations during the tour made me realize that this understanding was largely mistaken; he must in fact have observed the environment in the motif he wanted to create extremely carefully.

\section{Munch's House}

After the guided tour of Munch's House I wrote the log entry reproduced at the beginning of this article. This describes the moment I became actively engaged; no longer just a passive listener to what the guide told us about Munch's life, how he worked, his financial challenges and his love affairs. The picture of my own face in 
IImi Gutzeit Mathiesen.

In the Footsteps of an Observer - Looking at Edvard Munch in Åsgårdstrand

the mirror, as documented in my selfie (Fig. 2), somehow connected me to Munch. The imperfections of the old mirror produced an image with structures resembling Munch's use of painting tools, as in his self-portrait from 1886. The impression of the old house, where his clothes still hung, and the familiar surroundings, which somehow promised that he could show up at any moment, inspired me to think of Munch as alive and present - and thereby relevant to me in a way I had not expected. Munch was no longer just the famous old master who has been dead for decades. He was a person whose eyes had looked in the exact same mirror and who had taken in the exact same surroundings as me. Through my gaze and my agency, I became engaged with the "empathic participation" that, according to Barone and Eisner (2012, pp. 8-9), characterises arts based research.



Figure 2. Left: Edvard Munch "Selfportrait" 1886. Photo: Nasjonalmuseet/Børre Høstland (Free use. Creative Commons - CC-BY). Right: Selfie by the author in Munch's mirror, 2018.

\section{Researching with a portable studio}

In Åsgårdstrand, many small laminated plaques have been placed on fences and walls displaying images and information about the paintings Munch created in that particular location. They are often located precisely where the artist must have stood when capturing the motif. This educational device works well, as we can easily compare what Munch saw with what we see today. Time has stood still in many 
IImi Gutzeit Mathiesen.

In the Footsteps of an Observer - Looking at Edvard Munch in Åsgårdstrand

ways, especially in the area around his house. The streets are the same, and many of the wooden houses are still standing, exactly as they were when Munch found his motifs.

This realisation inspired me not only to walk in Munch's footsteps with greater care, but also to paint some of his characters into my own photos. My idea was, on the one hand, to investigate how realistically "faithful" Munch was in his renderings of landscapes and buildings, and on the other hand, to create an emotional connection to the famous paintings and to the life of Munch and his times.

I made my renderings on the tablet device I often carry with me - my own "portable studio". I used a touch-sensitive pen and software that allows me to paint a sketch there and then without having to bring any of my traditional painting equipment.

Painting Munch's figures directly onto the photos strengthened my connection to the landscapes he saw, and the landscapes as I see them today. By inhabiting the landscapes with "his" people, I not only "revived" the people but also the landscapes. I saw them as extensions of the figures I reproduced and not only as backgrounds. Through my own artistic agency, I was thus engaging with the "empathic participation" that characterises arts-based research.

Munch connects his figures and landscapes in striking and sometimes radical ways. Landscapes are not passive backgrounds, but seemingly play and interact with the figures. In his iconic work "Scream" (1893), Munch simplifies the landscape he observed, while emphasising the expression of inner experience in a way that goes far beyond a realistic landscape portrayal. The paint strokes of the sky are curved, matching the strokes in the trees and in the figure. Thus, the figure and landscape are woven together, reciprocally strengthening each other in conveying the utmost expression of anxiety and fear.

My own systematic use of artistic skills during the research process made me understand and examine the motifs in a meditative, almost suggestive way. To paint Munch's figures in this way engaged me both as a human and as an artist. I became compassionately involved in the figures' positions and what they express with their body language. By taking the time to repaint the figures, I had to interpret and understand them in a way that would not have been possible by simply "photoshopping" them onto my photographs. The slow process of reproducing lines and colours connected me to the painting through my own actions and bodily experience.

Below is an example of my method of reproducing the figures from a Munch painting into a photo taken from the place where he is likely to have stood. The photo, taken 
IImi Gutzeit Mathiesen.

In the Footsteps of an Observer - Looking at Edvard Munch in Åsgårdstrand

during the guided tour of Munch's house, has been kept as it was, but with the sunny spring daylight illuminating the beach, rather than the blue light of night that dominates the original painting.
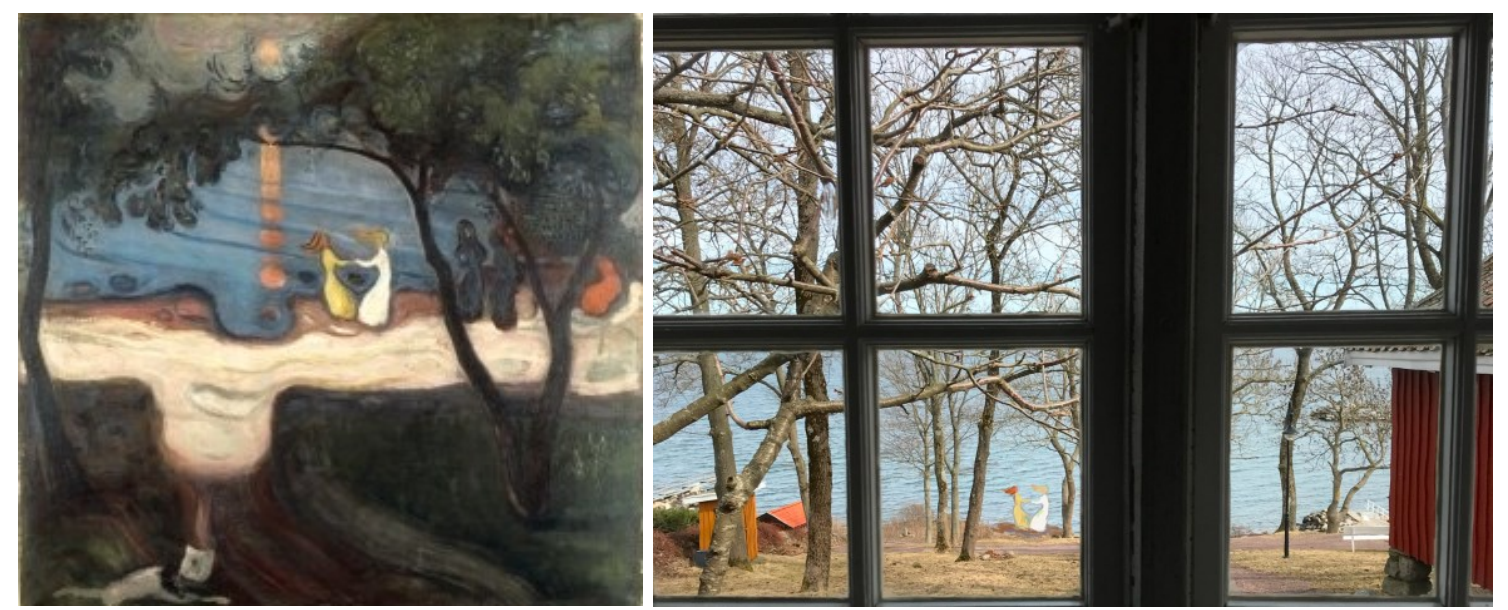

Figure 3. Left: “Dance on the shore” 1902 (Free use. Public domain). Right: A view from Munch's studio in Åsgårdstrand. Photo/painting by the author.



Figure 4. A view from Munch's studio in Åsgårdstrand. Detail from photo/painting by the author.

\section{Walking "with" Munch}

In the evening, after the guided tour, I took the same route, but this time alone.

Without any outer guidance, I was now more open to engaging with my own associations and reflections. I understand the act of walking as an actual part of the 
IImi Gutzeit Mathiesen.

In the Footsteps of an Observer - Looking at Edvard Munch in Åsgårdstrand

research process that provides essential information. When walking, experiencing the surroundings sensually is not only influenced by the observing eye, but also by the actual movement of the body in the terrain. According to Katrín Lund:

Walking is a bodily movement that not only connects the body to the ground but also includes different postures, speeds and rhythms. These shape the tactile interactions between the moving body and the ground, and play a fundamental part in how the surroundings are sensually experienced. (Lund, 2005, p. 28).

Walking invites us to pay attention to our senses by slowing down and making us more aware of the surroundings and our experiences. For the researcher, this provides "access to experiences that are multi-layered, sensory, and affective, which help us reach beyond the personal to social understandings" (Irwin, 2013, p. 104). In line with Sarah Pink's sensory ethnography, which highlights multisensory experience and bodily presence, "walking with others - sharing their step, style and rhythm creates an affinity, empathy or sense of belonging with them has long since been acknowledged by ethnographers" (Pink, 2009, p. 76). Although I did not actually walk with Munch, I was still influenced by his "presence" through my knowledge of his iconic artistic representations of the environment that surrounded me, and which I was now a part of. I would argue that through this process I was developing an "experience-based empathetic understanding" of Munch and the environment that inspired him (Pink, 2009, p. 65).

With the knowledge from the guided tour in mind, I had brought my tablet and could now spend more time searching for the spots where Munch must have stood when first becoming aware of the motifs he would paint. Åsgårdstrand was very quiet this April evening, with mostly dark windows, few cars and empty streets. It felt strange to walk along the same beach where Munch must have walked when he was inspired to paint "Melancholy", often labelled the first symbolist work by a Norwegian painter (Eggum, 1983, p. 75). I passed the big rock behind the man who rests his head in his hand. I touched the rock, placing my hand on the rough surface. Did Munch also do this? Did he touch this very rock? The warmth from the April sun could still be felt. Walking over small and large rocks is not easy, in some places you stumble, and stagger forward.

As I was taking pictures from the place where Munch most likely stood when he got the idea for "Melancholy", a saying came to me: "Don't judge a man before you have walked in his shoes for a whole day". I noticed that I once again started to identify with Munch, just as I did when looking into the mirror in his house earlier that day. I 
was no longer just the observer. I began to re-live what might have been that summer night in 1899.


Figure 5. Left: Munch, 1892. "Melancholy" Photo: Nasjonalmuseet / Jacques Lathion, (Free use. Creative Commons - CC-BY). Right: Photo by the author from the same vantage point. The man is painted directly onto the photo, to underline where Munch most probably stood.

Later, I used my photo from the rocky beach to "paint in" the man portrayed in the foreground of the original painting. This again strengthened my understanding that Munch painted his motifs from observations, and not from imagination and visions alone. The perspective from where he is likely to have stood shows that Munch faithfully reproduced the landscape, the location of the white house and the relationship between the larger stones.

The man in Munch's painting has his head resting heavily in his hand, his introvert glance expressing melancholy and despair. It was challenging to copy the body language and to place the man correctly in this landscape. Struggling to get it "right" gave me a surprising ownership of the motif, widening my understanding of the choices Munch must have made when processing what he saw at the beach in Åsgårdstrand in the summer of 1892. Exploring Munch's "Melancholy" through the camera lens and re-painting his main figure gave me new insight and understanding of the his choices, both with regard to the degree of realistic representation from that particular viewpoint, and regarding symbolically representing the emotional content of "melancholy" as a concept and a human emotion (Eggum, 1983, p. 83). Overall, I experienced that "reproducing" Melancholy strengthened my position as an artistic connoisseur (Eisner, 1998). I used my skills and repertoire as a visual artist - my insider knowledge - and contributed in this way to developing my own connoisseurship.

\section{Art and imagination}

Another example of the results from my evening walk is based on "Street in Åsgårdstrand" painted in 1902. The first thing I noticed is how correctly the perspective is interpreted. When comparing the painting with the view of the street 
today, I notice that the fence is still there and most of the houses are placed just as Munch would have seen them.


Figure 6. Left: Munch: Street in Åsgårdstrand (1902). (Free use. Creative Commons - CC-BY). Right: Photo/painting by the author.

Exploring Munch's viewpoint, I not only saw how the fences and houses were carefully observed and correctly rendered in his painting. In the quiet afternoon, with no sounds from traffic and no people around me, I had a vision of the girl who Munch portrayed. She was standing right in front of me - staring at me with her blue eyes, the blue dress neatly hanging from her thin shoulders. When "seeing" the girl in front of me, my imagination obviously played a part in my investigation. This experience is perhaps not particularly scientific, but still, as Barone and Eisner argue, the imagination can be a useful tool for exploring new dimensions of a subject and the fictitious can play an important part in art based research (Barone \& Eisner, 2012, p. 101).

\section{Munch as a photographer}

Munch was strongly interested in photography as an art form and was one of the first in his generation of painters to use a camera, acquiring his first camera in 1902 at an age of nearly 40 . Munch is known for having considered photography to be just as worthy an art form as painting. In an article for the Norwegian magazine Kunst og Kultur (date unknown), Munch wrote: "mechanical production made by a judicious hand can provide good results" (Stanska, 2016).

When Munch died in 1944, he left 183 photos, none of which were exhibited during his lifetime (Stanska, 2016). Munch learned the basic techniques of photography and experimented with double exposures, unconventional angles, shutter speeds and focus. Sometimes, some of the characters are out of focus while others are clearly delineated in one and the same photo (Eggum, 1987, p. 130; Holt, 2013, p. 32). Munch took "selfies" at a time when few people did; holding a camera with his arms 
IImi Gutzeit Mathiesen.

In the Footsteps of an Observer - Looking at Edvard Munch in Åsgårdstrand

extended and snapping a picture, while obviously posing for the shot. He also made ink drawings on some of his prints in a way that clearly resembles my own approach - the photograph is used as a starting point for artistic experimentation and adaptation. Many of Munch's photos can be seen as pre-studies for his paintings and are thereby a vital part of his artistic process. In essence, in his photographic work, Munch used a research-based approach to art.

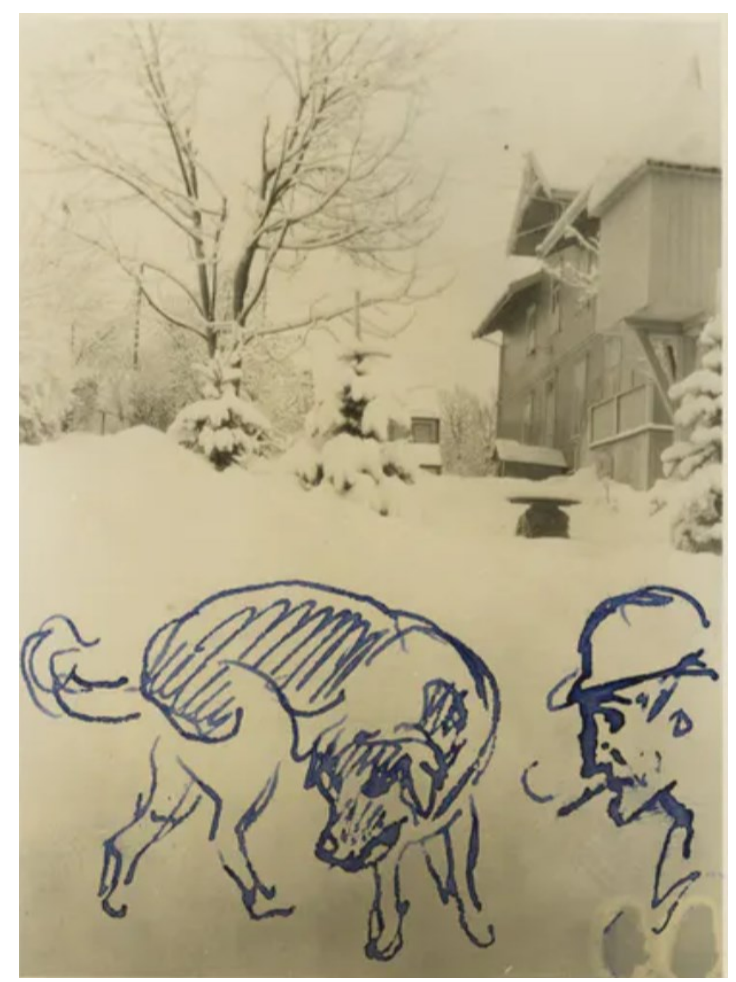

Figure 7. From Munch's property at Ekely. Postcard with Munch's drawing (1927). (Free use. Creative Commons - CC-BY).

"The brawl", the background of which is a street in Åsgårdstrand, is painted in Munch's later life, at a time when he no longer had a close connection to Åsgårdstrand. The perspective and photo-realistic depiction of the background makes it tempting to believe that he might have based this painting on a photo, although there is no evidence to this end. To me, it is not of major importance whether or not this is the case. His earlier paintings show that he was absolutely competent in drawing realistically if he chose to do so. 

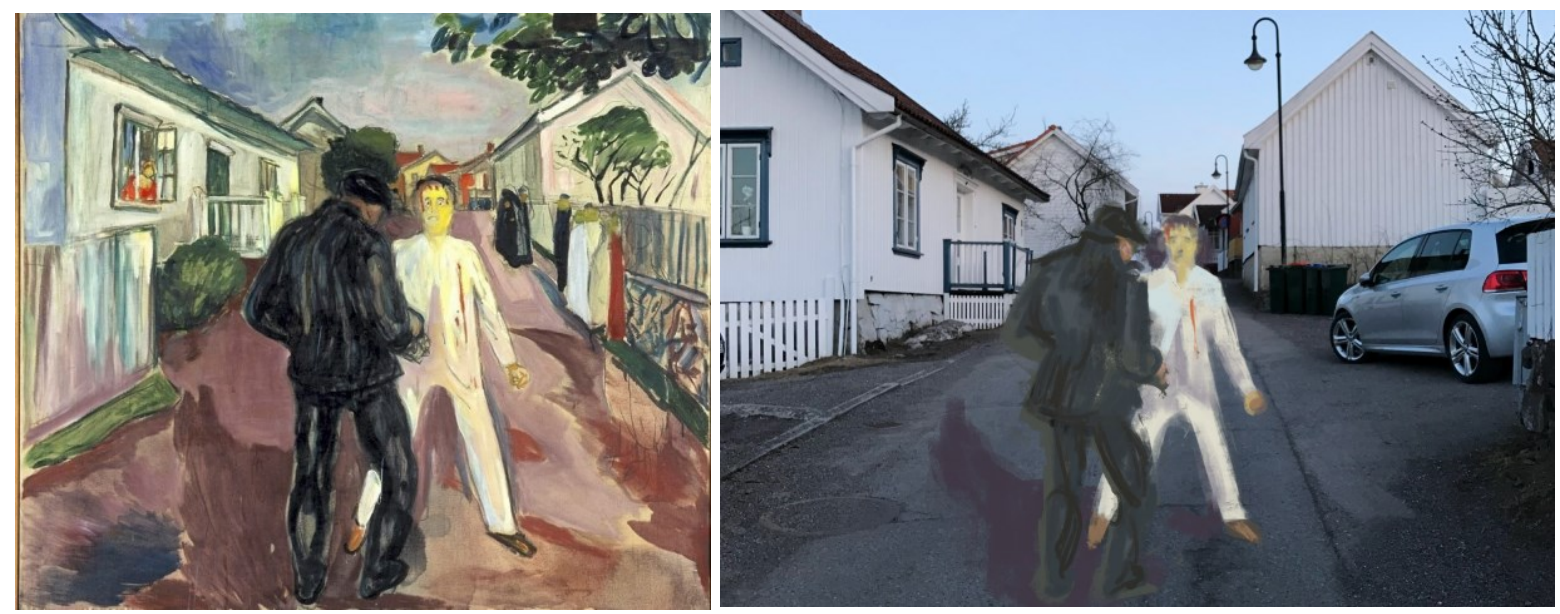

Figure 8. Left: Munch (1935): "The brawl”. (Free use. Creative Commons - CC-BY). Right: photo by the author of the same street with almost the same viewpoint.

\section{An educational approach}

As I have shown in this article, "walking in the footsteps" of Edvard Munch formed part of my own learning process aimed at exploring the artistic gaze and also obtaining a more intimate and personal experience of a famous artist and his work. I would argue that this approach may be relevant in an educational setting and offer some ways in which my approach to Munch's life and works can inspire art students and other artists.

My study highlights the value of a direct, hands-on learning experience and the necessity of leaving the classroom or studio to see for oneself the landscapes and environments that an artist's motif is based on. This makes it possible to compare reality and the artist's interpretation. For me, walking in the Åsgårdstrand landscape, trying to understand where Munch might have stood when he captured the motif for "Melancholy" was an awareness-raising, bodily and emotional experience.

I suggest that this kind of educational approach can give students a closer relationship to an artist and an artwork. Investigations made there and then can reinforce and enhance art education practices in an experience-based manner. Other artists can obviously be explored in the same way, either by means of painting images onto photos of motifs or by walking in their footsteps and visiting locations where they lived and worked. In Norway, for example, the works of Oluf Wold Torne, Thorvald Erichsen and Henrik Sørensen can be seen at Holmsbu art gallery just south of Oslo. These three artists lived and worked in Holmsbu and interpreted the landscape that surrounded them. Other famous artists that can be approached in the same way are Nikolai Astrup (Western Norway), Harald Sohlberg (Mid-Norway) and Karl Erik Harr (Northern Norway). While not many artists have laminated plaques dedicated to them providing images and information about the paintings made in that specific location, it will in many cases be possible to discover the artist's vantage 
IImi Gutzeit Mathiesen.

In the Footsteps of an Observer - Looking at Edvard Munch in Åsgårdstrand

point. Searching for such points, and exploring the landscapes where the artist must have stood, can be an eye-opening learning experience.

Using a "portable studio" to document the landscape to be investigated can obviously be beneficial in an educational setting. The possibility of becoming an active participant will sharpen the students' gaze and stimulate interest. Photos taken with a tablet device can be used as a direct base for further processing, making adjustments and drawing figures into the motif. Students in various contexts can use the technique of digitally combining photos and brushstrokes or other procedures. Combining photos and painting on the same device suits the learning process well, and with a tablet, it is easy to get started with investigations and artistic experiments there and then. Bringing this approach into education can inspire and enrich young people's art experiences by exploring the work of great artists with their own minds and bodies.

\section{Arts based research - research based art}

In this project, I have used my own artistic expression as a means of enquiry close to the sense of "artistic knowing" (Borgdorff, 2012, p. 21; McNiff, 2011, p. 38). In the act of painting Munch's figures onto photos, I actively drew upon my skills as an artist. This insider knowledge - my connoisseurship - informed my work as I, with great care, placed the figures in the "right" positions. I integrated my own artistic activities into the research process, using the artist Munch and his paintings from Åsgårdstrand as the basis of my study. I not only tried to "walk in Munch's shoes", but also to engage with his gaze by "looking through his eyes". In the process of finding the vantage points where he must have stood, and painting his figures onto my photos, I experienced a connection to Munch that gave me a better understanding of his artwork and possibly also of his approach to painting. Using arts based research as a method by systematically employing my own skills as an artist, I found that his gaze was accurate and sometimes sensationally exact; yet he never forgot his idea or inner vision. It became clear to me that Munch's paintings are closely based on the surroundings and the people who inhabited them, but they are much more than artistic translations of what he saw - there is always an interpretation.

In this article, I have employed an arts based approach to investigating Munch's work through my own observations and artistic agency, an approach that also has implications for art in education. My work engaged me on an emotional and empathic level, leading to new understandings. While much of the present discourse surrounding Munch and his work elevates him to an iconic status, practically a cliché in line with the classical artist myth of the distanced and unapproachable genius, my experience through "walking in his footsteps" gave other images of the artist. I 
IImi Gutzeit Mathiesen.

In the Footsteps of an Observer - Looking at Edvard Munch in Åsgårdstrand

developed a personal engagement that made him clearer to me as an observing, reflecting and engaged human being.

While I place my own project within the framework of arts based research, to conclude this article I would argue that we might understand much of Munch's work as research based art. This concept entails that the use of research in any modality serves as a basis for creating a work of art (Barone \& Eisner, 2012, p. 9). I understand Munch's experiments with photography and his artistic explorations of perspectives, abstractions and symbolic interpretations of landscapes as deliberate research methods for exploring the motifs he was engaged in producing. Munch artistically researched the subjective emotions and responses that landscapes, objects and people produced in him. Through engaging with his work by "walking in Munch's footsteps" and through my own hands-on artistic experimentations, I arrived at a better understanding of Munch. Not only was he a precise and careful observer with great artistic talent, he also based his work on explorative methods that contain a strong aspect of research as well. In essence, Munch was a researching artist, he was making research based art.

\section{About the author}

IImi Gutzeit Mathiesen is a visual artist and associate professor at the department of Art, Design and Drama, faculty of Technology, Art and Design at Oslo Metropolitan University, where she teaches and conducts research activities in the visual arts field. Mathiesen is a member of the research group Art in Society at OsloMet. As a visual artist, Mathiesen has participated with drawings and sculptures in numerous exhibitions in Norway and abroad.

\section{References}

Almqvist, C. F., \& Vist, T. (2019). Editorial Special Issue on Arts-Based Research. European Journal of Philosophy in Arts Education, 4(01), 4-26.

https://doi.org/10.5281/10.5281/zenodo.3572351

Barone, T., \& Eisner, E. W. (2012). Arts Based Research. Los Angeles: Sage.

Berger, J. (2008). Ways of seeing. London: Penguin books.

Borgdorff, H. (2012). The conflict of the faculties: perspectives on artistic research and academia. Leiden: Leiden University press.

https://doi.org/10.26530/OAPEN 595042

Eggum, A. (1983). Malerier - skisser og studier. Oslo: J.M. Stenersens forlag A/S.

Eggum, A. (1987). Munch og fotografi. Oslo: Gyldendal. 
IImi Gutzeit Mathiesen.

In the Footsteps of an Observer - Looking at Edvard Munch in Åsgårdstrand

Eisner, E. W. (1998). The enlightened eye: Qualitative inquiry and the enhancement of educational practice. New Jersey: Prentice Hall, Inc.

Ekebergparken. (2013). Marina Abroamovic - The Scream. Retrieved 05.06.2020 from https://ekebergparken.com/en/kunst/scream

Holt, C. T. (2013). Edvard Munch Fotografier. Oslo: Forlaget Press.

Irwin, R. L. (2013). Becoming A/r/tography. Studies in art education, 54(3), 198-215. https://doi.org/10.1080/00393541.2013.11518894

Langer, S. K. (1957). Problems of Art. New York, USA: Charles Schribner's Sons.

Lund, K. (2005). Seeing in Motion and the Touching Eye: Walking over Scotland's Mountains. Etnofoor, 18(1), 27-42. Retrieved 28 January 2021, from http://www.jstor.org/stable/25758084

McNiff, S. (2008). Arts-based research. In J. G. Knowles \& A. L. Cole (Eds.), Handbook of the arts in qualitative research: perspective, methodologies, example and issues (pp. 83-92): Sage Publications.

McNiff, S. (2011). Artistic expressions as primary modes of inquiry. British journal of guidance \& counselling, 39(5), 385-396. https://doi.org/10.1080/03069885.2011.621526

McNiff, S. (2013). Introduction: A critical focus on art-based research. Journal of Applied Arts \& Health, 4(1), 5-12. https://doi.org/10.1386/jaah.4.1.5 1

Munchmuseet (2015). Melgaard + Munch. The end of it all has already happened. https://munchmuseet.no/en/exhibitions/melgaard-munch

Pink, S. (2009). Doing sensory ethnography. Los Angeles, London: SAGE Publications Ltd.

Stang, R. (1977). Edvard Munch - Mennesket og kunstneren. Oslo: H. Aschehoug \& co (W. Nygaard).

Stanska, Z. (2016). Edvard Munch's Life In Photos. Daily Art Magazine. Retrieved 06.06.2020 from http://www.dailyartmagazine.com/edvard-munchs-life-inphotos/

Østern, T. P. (2017). Å forske med kunsten som metodologisk praksis med aesthesis som mandat. Journal for Research in Arts and Sports Education, 1(0). https://doi.org/10.23865/jased.v1.982 